\title{
Influence of Authoritarian Parenting Style on Forms of Delinquent Behaviour Among Secondary School Students in Butere Sub- County, Kenya
}

\author{
Judith Kivandi Buliva \\ Masinde Muliro University of Science and Technology, Kenya \\ Dr. Samuel. N. Maragia. \\ Department of Educational Psychology, Masinde Muliro University of Science and Technology, Kenya \\ Dr. Moses W. Poipoi \\ Department of Educational Psychology, Masinde Muliro University of Science and Technology, Kenya
}

\begin{abstract}
Forms of delinquent behaviour amongst secondary school students continue to increase thus hindering effective learning by students leading to poor academic performance in national examinations. The study sought to determine the influence of Authoritarian parenting on forms of delinquent behaviour among secondary school students in Butere Sub-County. The study was based on the Parenting Models theory. It adopted a correlational research design which allowed the researcher to describe different events, experiences, or behaviours and look for links between them. Study data was collected using a questionnaire and an interview schedule. Population of the study comprised of 2797 form two students, 30 deputy principals and 30 teachers in charge of guidance and counselling in secondary schools in Butere Sub-county. The study sample comprised 338 students selected using simple random sampling, 10 deputy principals and 10 teachers in charge of guidance and counselling. Both descriptive and inferential statistics were used in data analysis. Study findings showed that there was a statistically significant and positive relationship between Authoritarian parenting style and forms of delinquent behaviour among secondary school students in Butere Sub-County. The study recommended that parents consider spending quality time with their children in order to monitor them for any signs of forms of delinquent behaviour, and inculcating in them desirable societal values. Family systems need to be strengthened so as to provide the communal counselling services for both parents and youth and to promote family education related to child upbringing.
\end{abstract}

Keywords: Authoritarian, Parenting Style, Delinquency, Students

DOI: $10.7176 / \mathrm{JEP} / 10-19-01$

Publication date:July $31^{\text {st }} 2019$

\subsection{Introduction}

Delinquent behaviour refers to a wide range of anti-social acts often associated with individuals who are below 18years and often include: drug abuse, weapon carrying, vandalism, alcohol abuse, drug and substance abuse, school violence, bullying, truancy, school drop-out, rape, sexual indulgencies among many others (Withers, 2014). The contributing factors for the development of delinquency include, but are not limited to, peer influence, lack of education, family problems, poverty, substance abuse, childhood maltreatment, proximity to violence, low intelligence, certain genetic traits, neglect and abuse (Cardoso, 2012; Withers, 2014). However, a great deal of research findings suggests that the family unit is probably the single greatest determinant of delinquent behaviour (Withers, 2014). Family environment, which includes parenting style and family structure, contributes significantly towards impacting a child's development of delinquent behaviour, partly because children spend alot of their time with parents who play an influential role in moulding and shaping their behaviour. From this perspective, Coste (2015) recognizes the work of Baumrind, a clinical as well as developmental psychologist best known for her work on parenting styles. Baumrind identified three parenting styles based on parental demandingness and responsiveness, which included authoritative parenting, authoritarian parenting, and permissive parenting. Hoeve, (2009), points out that young people's parents are more frequently blamed for the criminal or delinquent behavior displayed by their children. Some of the courts even penalize parents for the inconsiderate or antisocial conduct of their children.(Hoeve, et.al 2009)

In Africa, detailed information on youth delinquent behaviour is scanty, with the absence of reliable databases in most countries, although countries. However, there is evidence of increasing law-breaking among young people. Victimization surveys in several countries, as well as qualitative observations, suggest delinquency among young people (12-25 years) is increasing at a much higher rate than in the developed north. This includes in particular, violent behaviour, drug-related offences, and gang activity (Ogidefa, 2008). In Douala, Cameroon, for example, crime, violence and insecurity have increased in recent years, especially in 
informal settlements and difficult neighbourhoods. A major influence on young people has been the so-called Feyman, white collar criminals and corrupt officials who are able to get away with offending without prosecution, and have become a source of admiration and inspiration for the young (Nwankwo,2006).

In Kenya, the situation is worse in our educational institutions where youth deviant behaviour has resulted in destruction of property worth millions of shillings and loss of lives; for example, the Endarasha Secondary School in Nyeri County case where a strike resulted in the death of two students. This kind of situation is worrying bearing in mind that the youth are valuable assets in development of any country (Daily Nation, Saturday 17th 2010). Aloka and Bujuwoye, (2013), contends that, behaviour problems among Kenyan secondary school students have been on the rise over the years and cite examples such as in the year 2001 where some students used petrol to burn a Kyanguli Boys' Secondary school's dormitory and some 68 students died in the inferno.

Both 2002 and 2005 also witnessed cases of arson by students in different secondary schools in Kenya, (Aloka, 2012). Kariuki (2014) contends that parents are the first socializing agents for their children's behaviour. It is common practice for parents to teach their children social rules and roles by explaining, rewarding and punishing them. However, sometimes parents unconsciously socialize the conducts they may not want their children to adapt. As such, parents are often blamed when children engage in antisocial behaviour. Some parents are warm, responsive and child centred in rearing their children. Other parents are rejecting, unresponsive, and essentially uninvolved with their children. On the other hand, some parents are demanding and restrictive on their children while others are permissive and undemanding. Like other parts of Kenya, Kakamega County, is experiencing high rates of juvenile delinquency as raised by government officials in the following article: 'Kakamega alarmed over rise in juvenile crime', Counties, News September 18, 2014 by Dennis Lumiti. Government officers raised alarm over the rising cases of juvenile delinquency in Kakamega County.

The officers said the number of children being arrested and locked up at the juvenile remand homes in the area is on the rise and challenged parents to spend more time with their children to improve their morals. The officers said parents are losing control over children, eroding discipline among them. They said most family units are under threat as "children are virtually taking over their families even with parents still alive". Lumiti, (2014). Butere is one of the sub-counties that form Kakamega County. The children's officer of this sub-county has noted that averages of 10 truant children are arrested every week in the sub county. Some of them are found to have dropped out of school and engage in child labour even with free and compulsory basic education having been put in place by the government and made into law through the basic Education act, 2010.

Research conducted by Butere Community Health and Development Association (BCHDA) and Great Lakes University of Kisumu (GLUK) indicate that teenage pregnancy among secondary school girls in Butere Sub-County, Kakamega County is rampant and alarming. According to the Research Team leader and the Association's Health advisor, research conducted in 31secondary schools in Butere indicated that majority of students especially girls were engaging in unprotected sexual adventures. (Kenya News Agency, May 28, 2015). This research revealed at least 72 cases of teenage pregnancies in schools with 42other girls confessing to have procured unsafe abortions. Drug abuse was also rampant with 41 male students acknowledging to be addicted to hard drugs such as Bhang, Cocaine and Hashish. From the preceding discussions, it appears that there is an upsurge of antisocial behaviour among adolescent secondary school students. The researcher therefore saw the need to find out the influence of parenting styles on forms of delinquent behaviour among secondary school students in Butere sub-county, Kakamega County, Kenya.

\subsection{Statement of the problem.}

The new constitution has many implications for Kenyan people's education, for their rights to education, and for their education services. Each county government is striving to ensure that its people have access to functional and quality education in line with Session Paper No 14 of 2012, Vision 2030, the Basic Education Act of 2013, as well as international commitments such as the Millennium Development Goals (MDG's) and Education for All (EFA). The national secondary enrolment significantly increased in 2008 when FDSE was implemented. The GER for the county in 2012 was $43.71 \%$ compared to the national figure of $46.6 \%$ indicating that the county stood at an NER OF 26\% compared to the national NER of 29.3\%. (Kakamega County Education Task Force Report, 2014). Based on national performance indicators, the situation of access, quality, learning environment and internal efficiency of Kakamega's Basic Education sector are relatively poor. Government officers have noted and raised an alarm over the increase in cases of some forms of delinquent behaviour among secondary school students in Butere Sub-County, Kenya that are making it difficult to achieve the goal of quality and functional education for all.

Despite the government's effort in ensuring that all secondary school age students access education through free day secondary school education funds, reported cases of drop out are on the rise as a result of students engaging in some of these forms of juvenile delinquent behaviour. The performance of the Sub-county in National exams has also been on the decline as a result of the increase in delinquent behaviour among secondary 
school students as reported by the Sub-County director of education Butere (DEO's office, Butere, 2017). The Butere sub-county annual report indicates that as at $30^{\text {th }}$ November, 2014, a total of 1,294 students dropped out of primary school with the figure at secondary being slightly higher. Reports from secondary schools indicate rampant absenteeism among students which eventually culminates into poor academic performance and eventual school dropout.

These reports attribute up to $70 \%$ of this problem to home based factors. Truancy, bullying, dislike of teachers, deliberate avoidance of tests, boycotts, fighting, smoking, theft, cheating in exams, rudeness, drunkenness, drug abuse, teenage pregnancy, sneaking out of school are some examples of manifestations of delinquent behaviour that have been recorded in secondary schools in Butere sub-county. Records held in secondary schools also indicate that form two students display frequent involvement in cases of delinquent behaviour. From the preceding discussions, it appears there is an upsurge of delinquent behaviour among secondary school students in the recent years and this has been blamed on parenting styles. The researcher therefore sought to find out the relationship between parenting styles and forms of delinquent behaviour among secondary students in Butere sub-county, Kenya.

\subsection{Objectives}

The specific objective of the study was to:

i. determine the influence of Authoritarian parenting style on forms of delinquent behaviour among secondary school students.

\section{4: Hypotheses}

H01: Authoritarian parenting style does not significantly influence forms of delinquent behaviour among secondary school students.

\section{5: Theoretical framework}

This study was based on the work of Diana Baumrind, (1991), a developmental psychologist who developed the most commonly used approach to assessing parenting styles. Her parenting typologies (authoritarian, authoritative, and permissive) (1967) have been used to assess parenting styles in several cultural communities across the world (Cheah, Leung, Tahseen, \& Schultz, 2009; Su \&Hynie, 2011; Yaman, Mesman, van IJzendoorn, \& Bakermans-Kranenburg,(2010). Baumrind's work is important to the study because her approach guided much of the conceptualization of the link between parenting and child outcomes. Baumrind (1991) designed a model on parenting styles and related it to their children's behaviour outcome. She identified responsiveness and demandingness as the parental behaviours that are desirable for child rearing. From the parental responsiveness and demandingness, she identified 3 general parenting styles; authoritarian, authoritative and permissive styles. According to Birgitte Coste, (2017), the parenting styles model has two axes. Each axis represents one of Baumrind's parenting themes which is 'high' in one end and 'low' in the other. Together these two axes of demandingness and responsiveness create four quadrants where each parenting styles is placed. The authoritative parenting style is high on demandingness and high on responsiveness (hence placed in the top left corner), the authoritarian parenting style is high also high on demandingness but low on responsiveness (hence placed in the bottom left corner) the permissive parenting style is high on responsiveness but low on demandingness (hence placed in the top right corner) and the neglectful parenting style is both low on responsiveness and low on demandingness.

\subsection{LITERATURE REVIEW}

\subsubsection{Parenting styles and forms of delinquent behavior}

Parental style refers to the way in which parents choose to raise their children. The way people parent is an important factor in their children's social emotional growth and development. In her research, Baumrind (1991) found what she considered to be the two basic elements that help shaping successful parenting: parental responsiveness and parental demandingness.

Through her studies, Baumrind identified three initial parenting styles: authoritative, authoritarian, and permissive parenting. This study adopted the three main parenting styles as raised by Baumrind and sought to establish the correlation between them and forms of delinquent behaviour among secondary school students in Butere Sub-County. Using data from the National Youth study of 1972,Weintraub and Gold as cited in Tadesse Membere (2016), examined whether parental supervision influences the level of self- reported delinquent behaviour among a representative sample of 1,395 11 to 18 year old Americans. Their analysis indicated that there is a relationship between the level of parental supervision and delinquency. Delinquency is one of the emerging concerns across the entire world. Siegel and Welch (2014) describe children's conducts that violate social laws as juvenile delinquency. They assert that some of the delinquent behaviours adolescents engage in are criminal, for example violence, stealing, and drug abuse. On the other hand, offences such as disobedience to 
school rules and truancy are status offenses. Status offenses are non- illegal yet are antisocial for children because they are underage (below 18 years).

Sigel and Welch view such children who engage in illegal acts as needing supervision, support and control for behaviour shaping.In this era of globalization, it has been indicated that the nature of offenses are becoming more violent (Siegel \& Welsh, 2014). Since the widespread of juvenile delinquency has become a social problem, it has become extremely important to study this problem and to evaluate the influence of parenting styles as an underlying cause of this behavior. Academic research tends to point out that family influence is one of the fundamental causes that leads the children to be delinquent (Farrington, 2010; Glueck \& Glueck, 2013). The cited incidences of delinquency in schools in the recent years seem to be blamed on parenting. Delinquent behaviours are manifested among high school adolescents as discipline problems (Kariuki, N. Scolastica, 2014). Parents play an influential role in molding and shaping the behavior of adolescents Juvenile is a time in which youth looks for self-identity and autonomy. Some of them engage in activities that are illicit in nature, and thus their parents become worried about their well-being. Juvenile delinquency is directly linked to the behavior that parents adopt as they raise their children (Coste, 2015). Houeve, et.al (2009) point out that parents are more frequently blamed for the criminal or delinquent behavior displayed by their children. Some of the courts even penalize parents for the inconsiderate or antisocial conduct of their children.

Talib, Abdullah, and Mansor (2011) on the other hand point out that the family of a child is a socio-culturaleconomic arrangement that has a significant influence on the behavior of the children, and also on the development of their characters. Therefore, ignorance in their parenting can lead them towards unwanted damaging effects that ultimately create behavioral problems in children. This study holds the same view as these researchers and sought to find out if the following forms of juvenile delinquent behaviour: running away from home, drugs, alcohol and substance abuse, bullying and teenage sexual indulgencies among students in secondary schools have any correlation with the parenting styles of their parents. Diana Baumrind is widely considered to be the pioneer of introducing parental style and control - authoritarian, authoritative, and permissive. From this perspective, Cherry (2015) points out that the psychologist Diana Baumrind during the early 1960s, conducted a study on children studying in preschool using parental interviews, naturalistic observation and other research methods. As a result, Baumrind identified four imperative dimensions of parenting including expectations of adulthood and control, communication styles, nurturance and warmth and disciplinary strategies. Based on the above mentioned dimensions, Cherry (2015) and Baumrind (1991) as cited by Membere Tadesse (2016), suggest that a majority of parents exhibit one of three mentioned parenting styles. This study adopted the parenting styles as proposed by Baumrind.

\subsubsection{Authoritarian Parenting and forms of delinquent behavior.}

According to Baumrind (1966) authoritarian parents are obedience and status oriented, they expects their orders to be obeyed without explanation. People with this parenting style often use punishment rather than discipline, but are not willing or able to explain the reasoning behind their rules. Authoritarian parenting is a style characterized by high demands and low responsiveness. Here parents have very high expectations of their children yet provide very little in terms of feedback and nurturance. Parents are often strict, tightly monitor their children, and express little warmth. They exhibit a large amount of control over the child's decisions and behavior; through a set of rigid rules with firm consequences. Children, who grew up in authoritarian home, often become anxious or withdrawn or suffer from self-esteem problems. These parents attempt to evaluate, shape and control the attitudes and behavior of their children based on these set standards of conduct, known as absolute standard where children are supposed to follow very strict rules defined by their parents. Cherry (2015) points out that authoritarian parents usually fail to come up with reasoning behind such rules. According to Hoskins (2014), authoritarian parents exhibit low responsiveness and they are highly demanding. In this style of parenting, emphasis is on conformity and obedience and thus parents expect that they are obeyed without explanation in a less warm environment. Authoritarian parents display low level of engagement and trust toward their children and more often discourage open communication and employ strict control of a child's behavior. An authoritarian parent is forceful, punitive and believes that a child should adhere to work in accordance to ethics and should be obedient. Here, parents are more concerned with the traditional family structure and therefore, limit the child's autonomy along with the parent-child relationship. Since the foremost concern of this parenting style rests within the traditional family structure, the child is expected to follow their parent's orders without any questions.

In Cyprus, researchers questioned 281 children about their cultural values and experiences with peers, they found that children from authoritarian homes were more likely to have experienced poor social skills (Georgion,et.,al,2013). The Netherlands in Dutch studies, children with authoritarian parents were rated as less helpful and less popular by their teachers and classmates, they were also rated as less mature in their reasoning about moral issues (Dekovic \& Jannseens, 2010). Studies of Spanish and Brazil have reported that children from authoritarian homes had lower self-esteem than did children from authoritative permissive families (Martinez and Garcia,2008) German researchers found that children with authoritarian parents were more likely to suffer 
from trait anxiety. Children of authoritarian parents feel unheard and under-valued as contributing members of the family unit. While these children are typically obedient due to the threat of negative parental consequences, they are emotionally hampered. Williams (2009), suggests that the authoritarian parenting style can lead to greater social withdrawal in children. Children raised in authoritarian environments have low degree of selfreliance and social competence as compared to children raised in authoritative environments (Lamborn,2010) Parents who practice authoritarian parenting demand total cooperation from their children and have no tolerance for questions or breaking the rules. This parenting style expects high degrees of maturity from their children with low parent-child communication

Adalbjamardottir and Hafsteinsson (2001), in a study of 347 youth from Reykjavik Iceland, noted that adolescents who characterized their parents as authoritarian were more likely to have tried smoking, drinking and drugs at age 14. The authoritarian parents attempt to evaluate, shape and control the attitudes as well as behavior of their children in line with set standards of conduct, known as absolute standard. In the light of this absolute standard, children are supposed to follow very strict rules defined by their parents. In case the children fail to comply with such rules they are punished. Cherry (2015) points out that authoritarian parents usually fail to come up with reasoning behind such rules. According to Nijhof and Engels (2007), the authoritarian parenting style is related with the lower level of ability and self-confidence to employ coping mechanisms among adolescents and thus restricts a child to explore his/her capabilities and social interactions, eventually resulting in the child's dependence on parental guidance and direction. Authoritarian child rearing typically require absolute obedience, are highly demanding and directive but not responsive .The parent provide well-ordered and structured environment with clearly stated rules. They have a history of unhappy childhood. They become anxious and withdraw for they have poor reactions to frustration. These parents often focus on punishment rather than reward. They tend to seek control in all areas of their child's life. Such children have little or no freedom. They are status oriented and expect their order to be obeyed, without explanation. They are high in behavioral control. The effect of this is that children become fearful of their parents.

Authoritarian parents talk to their children rather than with their children and do not consult with their children when making decisions (Alegre, 2011; Baumrind, 1971; Grolnick \& Pomerantz, 2009.) This one way communication does not give children space to express their needs and does not give children reasons for their expectations. Authoritarian parenting is restrictive, rigid, and punitive where parents pressure children to follow their directions and to respect their words and efforts (Timpano et al., 2010). Tompsett and Toro (2010) point out that the risk of adolescent's development of delinquent behavior is often headed by parenting style. Authoritarian parental style particularly plays an influential part in developing the delinquent behavior among adolescents that eventually results in negative outcomes (Kerr, Stattin \& Ozdemir, 2012). This study shared similar views with the other studies pointed above but noted that in these studies focus had been on younger children and not on juvenile secondary school going students.

\subsection{RESEARCH METHODOLOGY}

The study adopted a correlational research design. The design allows the researcher to describe different events, experiences, or behaviors and look for links between them (Shaughnessy, Zechmeister \& Jeanne, 2011). However, the design does not enable researchers to determine causes of behavior. Such a design is useful when the objective is to find out the relationships between variables but does not need to prove causation (Mugenda, 2008). The study was carried out in Butere sub-county, one of the nine sub-counties that form Kakamega County. The researcher chose this area because it has manifested an increase in the rates of juvenile delinquency among secondary school students (MOE Butere Sub-County reports, 2014; Butere / Khwisero Sub-County Childrens' officer's reports, 2014.) There were 30 registered public secondary schools in the study area. Three of these schools were for boys only, eight were for girls only and the other nineteen were mixed schools. The boys' only schools were all boarding, while only three out of the eight girls' schools were boarding. All the mixed schools were purely day schools. The study population comprised of 2797 form two students who were selected on the premise that for most of them this time was the onset of adolescence, 30 deputy principals and 30 teachers in -charge of guidance and counselling in Butere Sub-County. Students in the form two classes were also often involved in indiscipline cases. Form one students were still adjusting to secondary school life while the form three classes may have comprised of some students who fall beyond the juvenile age bracket. According to Best and Khan (2009) there is usually a tradeoff between the desirability of a large sample and feasibility of a small one.

The researcher therefore ensured that the sample was large enough to serve as adequate representation of the population about which generalization was made while at the same time being small enough for selection economically in terms of subject availability and expenses in both time and financial resources. The target population of the study (2797) was less than 10,000, the sample size used was as recommended by Mugenda \& Mugenda, (2013). A study sample of 338 students, 10 deputy principals and 10 guiding and counseling teachers was used in the study. Both questionnaire and interview methods were used in data collection. 
A pilot study was done in three schools in Butere sub-county that were not part of the schools that participated in the main study. Validity was ascertained using test-retest method while reliability was ascertained using Cronbach's Alpha test.

Data analysis was undertaken using both descriptive and inferential statistics were used. Descriptive statistics included measures of central tendency, measures of dispersion and measures of relative position. Inferential statistics used included Pearson product moment correlation coefficient, multiple regression and ANOVA.

Multiple regression was also used to determine the relationship as it was the best method to predict the values of the variables in the study (Regoniel , 2012)

Regression Model1.

$\mathrm{Y}_{\text {form }}=\beta_{\mathrm{o}}+\beta_{1} \mathrm{AN}+\mu$

Where:

$\beta_{\mathrm{o}}$ is a constant

$\beta_{1}$ is construct regression coefficient

$Y_{\text {form }}$ is forms of delinquent behaviour among secondary school students in Butere sub-County.

AN is Authoritarian parenting style

$\mu$ is the error term accounting for change in $Y$ that is not a result of AN.

Using SPSS (Statistical Package for Social Sciences), version 20, and the values of the coefficients analysis were obtained. This data was then presented.

\subsection{Findings}

There are 30 secondary schools in Butere Sub-County. Out of the 338 copies of the questionnaire distributed for the study, only 299 copies of the questionnaire were returned to the researcher by the respondents giving a response rate of $67.8 \%$. The respondents of the study comprised of $136(45.49 \%)$ boys and $163(54.52 \%)$ girls, 6 $(60 \%)$ male deputy principals and $4(40 \%)$ female deputy principals, $3(30 \%)$ male teachers in charge of guidance and counselling and $6(60 \%)$ female teachers in charge of guidance and counselling. Respondents were drawn from 3 Boys schools, 3 Girls schools and 4 mixed schools. Of these schools, 4 were boarding schools while the other 6 were day schools.

\subsubsection{Influence of Authoritarian parenting style on forms of delinquent behaviour.}

To determine the influence of Authoritarian parenting style on forms of delinquent behavior. To attain this data the researcher used a questionnaire for students and an interview guide for deputy Principals and Teachers in charge of guiding and counseling.

Table 1: Descriptive analysis for responses to authoritarian parenting style questionnaire

\begin{tabular}{|c|c|c|c|c|c|c|}
\hline & Authoritarian parent/guardian & $\mathbf{S A}$ & $\mathbf{A}$ & $\mathbf{S}$ & D & SD \\
\hline 1 & $\begin{array}{l}\text { Parental Aggression: Even if I don't agree with her, } \\
\text { parents/guardian feels that it is for my own good if I am } \\
\text { forced to conform to what she thinks is right }\end{array}$ & $\begin{array}{l}18.1 \% \\
(54)\end{array}$ & $\begin{array}{l}22.1 \% \\
(66)\end{array}$ & $\begin{array}{l}16.4 \% \\
(49)\end{array}$ & $\begin{array}{l}24.7 \% \\
(73)\end{array}$ & $\begin{array}{l}18.7 \% \\
(57)\end{array}$ \\
\hline 2 & $\begin{array}{l}\text { Hard discipline: My parents/guardian lets me know what } \\
\text { behavior is expected of me, and if I don't meet these } \\
\text { expectations, she punishes me. }\end{array}$ & $\begin{array}{l}47.8 \% \\
(143)\end{array}$ & $\begin{array}{l}31.1 \% \\
(93)\end{array}$ & $\begin{array}{l}8.0 \% \\
(24)\end{array}$ & $\begin{array}{l}6.4 \% \\
(19)\end{array}$ & $\begin{array}{l}6.7 \% \\
(20)\end{array}$ \\
\hline 3 & $\begin{array}{l}\text { Rigid rules: I know what my parents/guardian expects of me } \\
\text { in the family and they insists that I stick to those } \\
\text { expectations simply out of respect for their authority. }\end{array}$ & $\begin{array}{l}26.1 \% \\
(78)\end{array}$ & $\begin{array}{l}23.4 \% \\
(70)\end{array}$ & $\begin{array}{l}13.7 \% \\
(41)\end{array}$ & $\begin{array}{l}21.1 \% \\
(63)\end{array}$ & $\begin{array}{l}15.7 \% \\
(47)\end{array}$ \\
\hline 4 & $\begin{array}{l}\text { Parental lack of appreciation: My parents/guardian gets very } \\
\text { upset if I try to disagree with them. They do not appreciate } \\
\text { my point of view. }\end{array}$ & $\begin{array}{l}23.4 \% \\
(70)\end{array}$ & $\begin{array}{l}22.7 \% \\
(68)\end{array}$ & $\begin{array}{l}12.7 \% \\
(38)\end{array}$ & $\begin{array}{l}21.1 \% \\
(63)\end{array}$ & $\begin{array}{l}20.1 \% \\
(60)\end{array}$ \\
\hline 5 & $\begin{array}{l}\text { Parental harshness: My parents/guardian do not allow me to } \\
\text { question any decision they have made }\end{array}$ & $\begin{array}{l}12.0 \% \\
(36)\end{array}$ & $\begin{array}{l}10.0 \% \\
(30)\end{array}$ & $\begin{array}{l}5.4 \% \\
(16)\end{array}$ & $\begin{array}{l}37.8 \% \\
(113)\end{array}$ & $\begin{array}{l}34.8 \% \\
(104)\end{array}$ \\
\hline
\end{tabular}

*Total of scores was $100 \%$

Source: Research Data (2018)

From table 1 above, when respondents, were asked that if even they don't agree with parents, parents feel it's for their own good $18.1 \%$ strongly agreed $22.1 \%$ agreed while $24.7 \%$ and $18.7 \%$ disagreed and strongly disagreed respectively and on the idea that their parents let the respondent know the expected behavior $47.8 \%$ strongly agreed $31.7 \%$ agreed while 6.7 and $6.7 \%$ disagreed and strongly disagreed. As to whether the guardian insist that they stick to parents expectations $23.4 \%$ strongly agreed $22.7 \%$ agreed while $21.1 \%$ and $20.1 \%$ disagreed and strongly disagreed respectively. On parental harshness when asked whether parents do not allow respondent to question decision made, majority agreed as $34.8 \%$ strongly agreed $37.8 \%$ agreed while $12 \%$ and $10 \%$ disagreed and strongly disagreed respectively.Responses from interview guides pointed to absenteeism $(17.5 \%)$ petty theft $(15.1 \%)$ fighting $(9.4 \%)$ and intimate relationships $(3.9 \%)$ as being the most prevalent forms 
of delinquency among secondary school students. Responses from interviews also revealed that $31.1 \%$ of respondents were of the view that authoritarian patenting styles influence delinquency. Some responses (11.3\%) were of the view that authoritarian parenting style does not influence delinquency among secondary school students.

Correlation Analysis between Authoritarian parenting style variable and forms of delinquent behaviour among secondary school students in Butere sub-county was done and the following results in table 2 were obtained:

Table 2: Correlation Results for responses to authoritarian parenting style questionnaire.

\begin{tabular}{llll}
\hline & & Authoritarian & Forms of delinquent behaviour \\
\hline Authoritarian & Pearson Correlation & 1 & \\
& Sig. (2-tailed) & & \\
& $\mathrm{N}$ & 299 & 1 \\
Delinquent & Pearson Correlation & .027 & \\
behavior & Sig. (2-tailed) & .647 & 299 \\
& $\mathrm{~N}$ & 299 & \\
\hline
\end{tabular}

Source: Research Data (2018)

A correlation coefficient statistic that describes the degree of linear association between authoritarian and Forms of delinquent behaviour was determined. Table 2 indicates that there is a positive relationship between Authoritarian and forms of delinquent behaviour among secondary school students in Butere sub-county. This relationship has been illustrated by correlation coefficient of 0.027 which is not significant at 0.05 significant level. These results conform to previous studies done where authoritarian parenting styles had a significant relationship to forms of delinquent behavior. (Kerr, Stattin \& Ozdemir, 2012).

Results for Regression with Authoritarian parenting style and Forms of delinquent behavior. The results for regression analysis with Authoritarian parenting style are presented in table 3 .

Table 3: Model Summary for Authoritarian parenting style and Forms of delinquent behaviour

\begin{tabular}{llllll}
\hline Model & R & R Square & Adjusted R Square & Std. Error of the Estimate & Durbin-Watson \\
\hline 1 & $.027^{\mathrm{a}}$ & .001 & -.003 & .91077 & 1.729 \\
\hline
\end{tabular}

a. Predictors: (Constant), Authoritarian

b. Dependent Variable: Forms of delinquent behaviour.

Source: Research Data (2018)

The study determined whether there was autocorrelation through calculation of Durbin - Watson statistic. The statistic has to lie between1.5 - 2.5 (Garson, 2012). Durbin -Watson coefficient of 1.729 was realised and since it was between 1.5 and 2.5, there was hence no autocorrelation in the data residual. Thus, linear regression model was appropriate for this study. Ogundipe, Idowu and Ogundipe (2012) in their research used Durbin Watson test to determine whether there was autocorrelation in their data residuals. This justified the use of the regression model in their study.

Regression analysis was conducted to determine the amount of variation in Forms of delinquent behaviour explained by Authoritarian. The calculated $\mathrm{R}$ - value was $0.346 . \mathrm{R}^{2}$ value $=0.001$ which means that $0.1 \%$ of the corresponding variation in Forms of delinquent behaviour can be explained by change in Authoritarian. The rest $99.9 \%$ can only be explained by other factors that are not in the model.

ANOVA for Authoritarian parenting style results and Forms of delinquent behavior. The ANOVA for Authoritarian parenting style results are presented in table 4:

Table 4: ANOVA for Authoritarian parenting style and Forms of delinquent behavior results

\begin{tabular}{lllllll}
\hline Model & & Sum of Squares & Df & Mean Square & F & Sig. \\
\hline 1 & Regression & .174 & 1 & .174 & .210 & $.647^{\mathrm{a}}$ \\
& Residual & 246.362 & 297 & .830 & & \\
& Total & 246.536 & 298 & & & \\
\hline
\end{tabular}

a.Predictors: (Constant), Authoritarian

b. Dependent Variable: Forms of delinquent behaviour

Source: Research Data (2018)

A one way analysis of variance (ANOVA) that provided information about levels of variability within the regression model and which formed a basis for tests of significance was used. ANOVA for the linear model presented in Table above of Authoritarian parenting style and Forms of delinquent behaviour has an $\mathrm{F}-$ value $=$ 0.21 which is not significant with $\mathrm{P}$ value $=0.647$ meaning that the overall model is not significant in the prediction of forms of delinquent behaviour among secondary school students in Butere sub-county. The study therefore shows that Authoritarian parenting style has no influence on forms of delinquent behavior though there 
is a positive relationship with delinquent behaviour.

Coefficients for Authoritarian parenting style and Forms of delinquent behavior results

The Coefficients for Authoritarian parenting style results are captured in table 5.

Table 5: Coefficients for Authoritarian parenting style and Forms of delinquent behaviour

\begin{tabular}{llllllll}
\hline & \multicolumn{2}{c}{ Unstandardized Coefficients } & Standardized Coefficients & \multicolumn{4}{c}{ Collinearity Statistics } \\
Model & $\mathrm{B}$ & Std. Error & Beta & $\mathrm{T}$ & Sig. & Tolerance & VIF \\
\hline 1 (Constant) & 1.614 & .244 & & 6.614 & .000 & & \\
\multicolumn{1}{c}{ Authoritarian } & .035 & .076 & .027 & .458 & .647 & 1.000 & 1.000 \\
\hline
\end{tabular}

a. Dependent Variable: forms of Forms of delinquent behaviour behaviour

Source: Research Data (2018)

Multicollinearity was measured by variance inflation factor (VIF) or using tolerance. Variance inflation factor refers to a situation where two or more independent variables are highly correlated value $>10$ hence leading to multicollinearity problem. According to Maniagi, Alala and Egessa (2013) researchers have used $\mathrm{VIF}=10$ as critical value rule of thumb to determine whether too much correlation between independent variables in the study would undermine the reliability of the resultant coefficient of determination.. The VIF value in the table below less than 10 so there is no multi-collinearity problem. If multicollinearity increases, the regression coefficient can fluctuate from sample to sample hence complicating interpretation of the coefficient as an indicator of relative importance of predicting variables (Cooper \& Schindler 2003). Analysis of the regression model coefficients is shown in table below From the table there is a positive beta co-efficient of 0.035 for authoritarian as indicated by the co-efficient matrix with a $\mathrm{P}$-value $=0.647$ which is greater than 0.05 thus not significant and a constant of 1.614 with a P-value $=0.000<0.05$. Therefore, Authoritarian does not contribute significantly to the model. This did not conform to previous studies done by Kerr, Stattin \& Ozdemir, (2012), Tompsett and Toro (2010), and Timpano et all (2010), who contend that authoritarian parenting styles had a significant relationship to forms of delinquent behavior.

\subsection{Conclusion}

Based on the empirical evidence, the following conclusion is;

With regard to the first objective, study findings revealed that Authoritarian style has a positive relationship to forms of delinquent behaviour. This means that as use of authoritarian style increase forms of delinquent behaviour also increases though it's not significant.

\subsection{Recommendations}

In light of the findings and conclusions made, the following recommendations are made;

i. Parents to spend quality time with their children in order to monitor them for any signs of forms of delinquent behaviour .

ii. Parents/guardian advised to always encourage open discussion and give direction and guidance in rational and objective ways to students

\section{REFERENCES}

Ali. A. A., Dada, I.T., Isiaka G.A. \& Salmon S.A. (2014). Types, Causes and Management of Indiscipline Acts among Secondary School Students in Shomolu Local Government Area of Lagos State, Journal of Studies in Social Sciences (8), 2, 201-213.

Baumrind, D. (1991). The influence of parenting style on adolescent competence and substance use. The Journal of Early Adolescence, 11, 56 - 95. doi: 10. 1177/0272431691111004

Baumrind, D. (1996). The discipline controversy revisited. Family Relations, 45, 405- 414

Darling, N., \& Sternberg, L. (1993). Parenting style as context: An integrative model. Psychological Bulletin, $113,48-496$

Grogan- Kaylor, A. (2005). Corporal punishment and the growth trajectory of children's antisocial behavior.Child Maltreatment, 10, 283 -292.

Grolnick, W. S., \&Pomerantz, E. M. (2009). Issues and challenges in studying parental control: Toward a new conceptualization. Society for Research in Child Development, 3 (3), 165-170.

Hoeve, M., Blokland, A., Dubas, J. S., Loeber, R., Gerris, J. R. M., \&Laan, P. H. (2008). Trajectories of delinquency and parenting styles.Journal Abnormal Children Psychological, 36 , 223 - 235. doi: 10. 1007/s10802 - 007-9172-x

Hoeve, M., Dubas, J. S., Eichelsheim, V. I., Laan, P. H., Smeenk, W., \&Gerris, J. R. M. (2009). The relationship between parenting and delinquency: A meta-analysis.Journal Abnormal Child Psychology, 37,749-775.doi: 10.1007/s10802-009-9310-8.

Kariuki, N. Peter J.O. Aloka, K., Theresia, G., Nyaga H, and NdungeN.,( 2014). Relationship Between Adolescents' Perceptions of Their Parents' Behaviors and Youths' Non-Illegal and Minor- Illegal 
Delinquency in Nairobi Secondary Schools, Kenya,Mediterranean Journal of Social Sciences 5 (7) 1-13.

Kim, K. \&Rohner, R. P. (2002). Parental warmth , control, and involvement in schooling: Predicting academic achievement among Korean American adolescents Journal of Cross -Cultural Psychology, 33, 127140. doi: 10. 1177/0022022102033002001.

Knutson, J. F., DeGarmo, D. S., \& Reid, J. B. (2004). Social disadvantage and neglectful parenting as precursors to the development of antisocial and aggressive child behavior. Testing a theoretical model. Aggressive Behavior, 30, 187-205.doi: 10. 1177/1077559504273684.

Kombo, D. \& Tromp, L., (2006). Proposal and Thesis writing, An Introduction,Paulines Publications Africa, Kenya.

Leman, P. J. (2005). Authority and moral reasons: Parenting style and children's perceptions of adult rule justifications. International Journal of Behavioral Development, 29 (4), 265-270. doi: 10. 1080/01650250544000044

LumitiD. (2014) Kakamega alarmed over rise in juvenile crime', Counties, News September 18, 2014.

Marsiglia, C. S. Walczyk, J. J., Buboltz, W. C., \& Griffith-Ross, D. A. (2007). Impact of parenting styles and locus of control on emerging adults' psychosocial success. Journal of Education and Human Development, $1,1-11$.

Moitra N \& Mukherjee F., (2010). Does parenting behaviour impacts delinquency? A comparative study of delinquents and non-delinquents,International Journal of Criminal Justice Sciences.(IJCJS) 5, (2) 34-44.

Mugenda, O.M. and Mugenda G. A. (2012). Research Methods, Qualitative and Quantitative Approaches, Nairobi, Act Press.

Mugenda, O.M. and Mugenda G. A.(2013). Research Methods, Qualitative and Quantitative Approaches, Nairobi, Act Press.

Okorodudu, G. N. (2010). Influence of Parenting Styles on Adolescent Delinquency in Delta Central Senatorial District, Institute of Education Delta State University Abraka, Edo Journal of Counseling. 3, (1), 27-37

Gwen, D. (2016). Parenting Styles: A guide for the science-minded.

Schaffer, M., Clark, S., \& Jeglic, E. L. (2009). The role of empathy and parenting style in the development of antisocial behaviors. Crime \& Delinquency, 55, 586-599. doi: 10. 1177/0011128708321359.

Shahla A., Mansor B., Rohani A \&Mariani M., (2011). Relationship Between Parenting Style and Children's Behavior Problems, University of Putra Malaysia (UPM), Malaysi.

Sila, Esther Nthambi, (2011). Influence of Parenting Styles on Learners Self-Concept and Academic Performance in Kakamega East District, Kenya, Thesis, MasindeMuliro university of Science and Technology.

Solomon Ehiemua, (2014). Juvenile Delinquency: A Comparative Study Between Child Rearing Practices in Developed and Developing Countries ,European Journal of Research in Social Sciences. 2.(4),35-4.

Tanusree, M. \& Indrani, M. (2010). Does parenting behaviour impacts delinquency? A comparative study of delinquents and non-delinquents,University of Calcutta, India International Journal of Criminal Justice Sciences (IJCJS) 5 (2), $274-285$.

Underwood, M. K., Beron,K. J, \& Rosen, L. H. (2009). Continuity and change in social and physical aggression from middle childhood through early adolescence. Aggressive Behavior,35(5), 357-75.

Wesang'ula P, John O. \& Kabuka, K. ( 2010). Teachers' and Students' Perceptions of Psychological Factors Contributing to Violent Behavior among Public Secondary School Students in Western Province, Kenya, African Journal of History and Culture 2(6) 46-56.

Withers, R. (2014). Can Bad Parenting Turn a Child Into a Delinquent? Short answer: Yes. (C) Copyright 20142015 CounselingInsite -Blog Menu.

Wittenborn, M. (2002). "The Relations Between Parenting Styles and Juvenile Delinquency" Honors Thesis., Southern Illinois University Carbondale.

Wright, K, N. \& Wright, K. E. (1994). Family Life, Delinquency, and Crime: A Policymakers Guide. Research Summary. Washington, D.C: OJJDP: 4-21. 